Ph.D Harry Silfverberg is a senior lecturer of mathematics and science education at the Department of Teacher Education in the University of Tampere and a docent of mathematics education in the University of Joensuu in Finland. Nowadays he works as a director of a teacher education programme. His research interests include especially concept development processes both in mathematics and science, mathematics and science teacher education, and ICT-enhanced learning environments of mathematics (geometry).

\title{
HARRY SILFVERBERG
}

Department of Teacher Education, University of Tampere, Finland

harry.silfverberg@uta.fi

\section{The disappearance of light - explanations given by the primary school pupils}

\begin{abstract}
In the years 2004-2006 the National Centre of Professional Development in Education (Finland) and the Department of Teacher Education at the University of Tampere, Finland carried out together nine in-service courses under the title "Teaching physics and chemistry at grades 5 and 6". As a home assignment between three contact periods, I asked teachers to collect authentic material on their pupils' science thinking with the help of some carefully planned inquiry tasks. In the article, I present some examples of the most typical responses which primary school pupils gave to the question: "When the lights are turned off in a room on a dark winter night, the darkness will take over the room in the twinkling of an eye. Where do the rays of light which last left the lamp disappear?". The explanations were categorised under six metaphors describing the different ways of understanding the disappearance of light.
\end{abstract}

\section{INTRODUCTION}

Preconceptions regarding the phenomena of physics have been studied for a long time and a lot of research information about preinstruction learners' conceptions and representations has been accumulated. The database STCSE (Duit, 2006) maintained at the University of Kiel, for example, consists of about 7000 items within this field. As optics forms one of the traditional content areas of school physics, naturally many preconceptions related to this area have also been studied (Galili \& Lavrik, 1998; Langley, Ronen \& Eylon, 1997; van Zee, Hammer, Bell \& Roy, 2005). In Finland, where this study was conducted, significant work in this research topic was accomplished by Ahtee (1992), by Havu (2000), by Levävaara (1997) and by Rintakumpu (2001) among others.

Knowledge of the pupils' preconceptions and the skill to take preconceptions into consideration in teaching has become the core of the science teachers' professional competency. This way such matters, as

- knowledge of preconceptions

- arousing interest in the role of preconceptions in the learning process and paying attention to pupils' preconceptions in teaching

- understanding of the reasons for the formation of preconceptions and of their effect on the progress of the learning process

- skill of the studying children's preconceptions,

have become increasingly important contents of the teachers' basic and in-service education. 
In Finland the legislation determines the core subjects to be studied by all pupils. The government determines the national objectives for education and the number of classroom hours allocated to each subject. The new Finnish National Core Curriculum for Basic Education 2004 determines that the subject "physics and chemistry" which before this had been taught from the grades 7 to 9 will in future also be taught in grades 5 and 6 in primary school. This change has significantly increased the need and call for in-service training for class teachers working on these grade levels. The data for this study was collected from the pupils of the class teachers participating in the inservice courses which were arranged during the period 2004-2006. On the courses the teachers were introduced especially to methods whereby they could obtain information about their pupils' preconceptions and so better understand children's scientific thinking. Altogether 230 teachers participated in the nine courses from which the data was gathered. Even though I studied through the teachers a number of children's preconceptions related to many different phenomena, in this article I examine only the children's conceptions of one particular phenomenon i.e. the disappearance of light. The question which I asked the children was "When the lights are turned off in a room on a dark night where do the rays of light which last came from the light bulb disappear?" [Direct translation from Finnish]

Even though many children's preconceptions relating to light phenomena have been studied, it seems that the main research question of this study i.e. where the children suppose that the light disappears has not been examined in earlier studies.

\section{THE CHILDREN'S IDEAS OF LIGHT}

Many studies show that it is difficult for the children to distinguish on the one hand the propagating, invisible light and on the other hand the static lightness of the objects caused by the light. In the classic study of this topic Guesne (1985) found that for 12 to 15-year-old children light often means either the source of the light or the lighted target, and not the invisible light which goes between the source of a light and the target of a light. The finding has been later confirmed in many other similar studies (for example Driver, 2000; Hierrezuelo \& Montero, 1988). When a context especially directs children to connect the light with a situation taking place in daylight, the light is easily identified with the targets lit by it. However, because in normal circumstances the light seldom goes through a totally empty state, it is also quite usual that the path of the light is illustrated with a visible beam of light in a dark space. To many children, the light seems to be invisible in light but visible in the dark.

According to the studies it is also difficult for children to estimate what part of the light in different conditions is reflected, scattered or absorbed. The studies by Guesne (1985) and Jung (1980), for example, show that many children and sub-teens suppose that the light directed towards the mirror causes the light spot on the mirror in the same way as when the light is directed toward paper. Thus the light is always seen as a light trace on the object it falls on. This probably partly explains the identifying of the light itself and its target as been stated above. It is interesting to notice that the way phenomena associated with the light have been comprehended in the course of the history of mankind often corresponds to those explanations which children spontaneously offer for the behaviour of light (see for example Dedes, 2005; Pavlos \& Panagiotis, 2005; Rintakumpu, 2001).

According to the studies children and partly also adults seem to assume that lights of different colours mix with the same way as, for example, the watercolours will mix. Reiner, Slotta, Chi and Resnick (2000) refer to a study where 95 per cent of high school level students supposed, that a red light when looked at through a blue filter, appears to be purple. Still, after the first-hand observations showed the pupils that the colour actually was black, the students persistently claimed that it was just an illusion and due to the fact that the purple colour created, was too dark to be distinguished from the black. The similar results have been reported, among others, by Andersson and Kärrqvist (1982), Olivieri, Torosantucci, and Vicentini (1988) and Slotta, Chi, and Joram (1995). 
Brophy and Allemani (2003) interviewed 216 children and found that three out of four children knew that electricity is needed to produce electric light and that with a switch we can regulate when the lamp gets electricity and when not. However, most of the children could not explain how the electricity actually causes the lighting of the light in the lamp. Those children who evinced assumptions regarding the connection of a light and electricity proposed, among others, the following explanations: the power company or the manufacturer of the lamp has installed inside the lamp something that will light when the lamp gets electricity; if necessary, one can catch lighting fire to the lamps; the electricity shines normally but the shining is seen only in the lamp because the cables have been peeled from it.

Reiner et al. (2000) emphasise regarding the foregoing that many misconceptions and preconceptions which are related to novices' physical reasoning are due to attempts to apply the explanation models related to the material macro world to light, heat and electricity. Reiner et al. on the basis of earlier studies note four misconceptions characteristic of the children's and novices' thinking about light expressing the transfer of explanation models known to the material world also concern light. These are:

- light flows and can be at rest

- light mixes as if it were a liquid

- light creates friction upon contact

- light, colour, and shadows are something inherent in an object.

\section{PRECONCEPTIONS AS METAPHORS}

When children's ideas are studied, the difference in the children's language and the language used by the experts causes a difficult methodological problem. In many situations the child presumably means something other that what he/she literally says.

This is especially the case when the child is asked something difficult to answer and, if the situation according to the child's interpretation does not allow him/her to leave the question unanswered. When the child, for example, explains that 'the light will evaporate into the air', it is difficult to know whether he/she in this case really believes in the evaporation of the light and even in the evaporation into the air or if we should interpret the expression chosen by the child as a metaphor the conditions and how the light disappears out of the sight of an observer. As Lakoff and Johnson (1999) have noted abstract concepts are largely metaphorical. This means that most of our nonphysical reality is conceptualized via physical reality. According to Tolska (2002) the metaphor is used to describe children's new experience and to taking possession of events for which he/she does not at that moment have suitable concepts. The metaphor is a tool whereby the child gradually adapts his language to the constant enlarging and change of his or her experienced world. However, as Kövecses (2005) have pointed out metaphors do not occur primarily in language but in thought. We actually understand the world with metaphors and do not just speak with them. Happonen (2000) indeed states that in metaphor rational thinking and imagination combine, offering the child the frame which helps the child to connect matters which he/she already understands to those matters which he/she is only trying to understand.

In the research on mathematics education it has been fairly usual to use metaphors as an instrument to describe both pupils' and teachers' ways of thinking (see, for example, Mahlios \& Maxson, 1998, 2004; Martinez, Sauleda \& Huber, 2001; Presmeg, 1992, 1998 and 2004). In science education it has been common to use analogies and models as a tool in corresponding situations (Saari, 2000; Saari \& Viiri, 1998). The concepts 'metaphor', 'analogy' and 'model' are partly overlapping and differ mainly in how well the phenomenon to which we refer by the construction is conceptually organised. In the following I use the concept metaphor systematically because the children whom I examined described the disappearing of the light mainly through figures of speech and I 
take this as an indication that the children did not have a clear model of the real nature of this phenomenon.

\section{IMPLEMENTATION OF THE STUDY}

\section{Data collection}

During each of the nine in-service courses, I gave the participants two series of inquiry tasks to be done between the contact periods of the course with the help of which they were to study the special characteristics of their pupils' science thinking. After collecting the material the teachers were asked to categorise the explanations given by the pupils based on their own understanding. They were also asked to write themselves as credible an explanation as possible for the phenomena that the problems addressed.

The general instruction for the inquiry tasks was the following:

Choose at least two of the given problems and

a) write yourself as good an explanation as you can for the phenomenon described;

b) find out what kind of explanations your pupils give for a problem and collect and classify the different explanations;

c) think how the pupils' explanations differed from your own assumptions about the pupils' way of perceiving.

Of the eight to ten themes examined during the course I discuss here only the answers to question b) below:

a) When the lights are turned off on a dark winter night, the darkness will take over the room in the twinkling of the eye.

b) Why will the darkness come so suddenly?

c) b) "Where do the rays of light which last came from the light bulb disappear?"

The data collection of the study was carried out so that each teacher participating in the inservice course asked his/her pupils or his/her colleague's pupils to answer the above-mentioned question, and after which each teacher classified the pupils' answers according to his or her own interpretations. Even thought it was not in fact required of the teachers, some of the teachers also returned to me copies of pupils' $(n=93)$ original responses in addition to the classified. These responses were used as an additional material for the analysis of children's preconceptions even if it is impossible surely to know how representative sample this collection was from all the pupils' conceptions. The exact number of pupils who answered a task is not available because the teachers did not always report the total number of pupils providing answers. However, we can approximate the number of pupils. If we suppose that each of the 230 teachers had about 20-25 pupils in his/her class and about half of the teachers chose to study this task, there were at least 2000 pupils who actually did the task. Our main practical purpose on the course was to make qualitative comparisons of the explanations given by pupils together with the participating teachers. The research reported here was a continuation of this process. Figure 1 presents the main stages how the data was collected and analysed. 

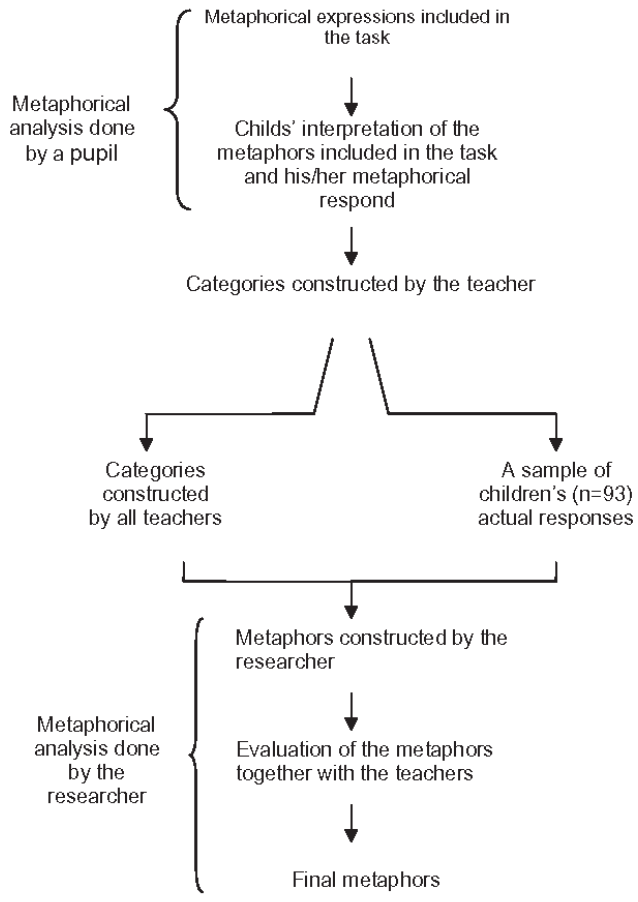

Figure 1. Phases of the metaphorical analysis.

\section{THE ROLE OF METAPHORS IN THE STUDY}

Because adults and children do not necessarily have a common language and concepts to deal with matters of this kind, the task itself unavoidably also itself becomes a metaphorical process. The adverb 'metaphorical' and the noun 'metaphor' refer in this paper to the process where an object or a phenomenon is described by a name or by a descriptive term to which the expressions are not literally applicable (cf. Presmeg, 2004). Expressions included in the question for example "...the darkness will take over the room ...", "the rays of light" and "... which last came from the light bulb disappear?" are actually metaphorical and may lead the children's answers in an unexpected way. Actually the expression "ray" for example can arouse two different images: the travelling light itself or the path of the travelling light. From the metaphorical point of view the Finnish word "valonsäde" resembles closely the English expression "ray of light". There were at least two stages in the study where metaphors played a crucial role (see the figure 1 above). The first one was engaged in the process of collecting the data. Answers containing metaphorical elements were obtained to questions which also contained metaphoric elements. The second one was connected to the interpretation of research findings in which the answers containing metaphorical elements were interpreted as wider metaphors of the more general level.

\section{RESULTS}

The teachers' descriptions and classifications of pupils' typical answers serve as a basis for the interpretations presented here. The collection of the 93 pupils' authentic answers obtained from teachers significantly supported our interpretations. In the following, the direct quotations presented have been selected from these pupils' original written answers. Most of the pupils' ideas about the disappearing of the light could be categorized under the following six metaphors. 


\section{Harry Silfverberg}

\section{The circulation metaphor}

In the explanations expressing the metaphor of circulation the light is returning to where it is thought to have come from. The children explained that the light disappeared to the electricity plant, to the nuclear power plant, to electric wires, inside the lamp, to the innermost section of the lamp, to the wall socket, to the fuse. In such explanations the light was also closely connected with the electricity which causes the light:

"Would it be the case that when the light disappears it changes into electricity and goes inside the walls in the electric wires?"

"The light disappears with the electricity away somewhere. The light will vanish away because the electricity will not come when the electricity is that light."

\section{The evaporation metaphor}

In many explanations, the light was reported to "evaporate into the air":

"The light evaporates and the darkness will come instead of it, when the light evaporates"

"...quick evaporating phenomenon of some kind."

"The lamp is so hot that the last rays which have come from it will evaporate."

In most cases the mechanism of the evaporating was not explained in any way. One pupil, however, tried to explain that the evaporating was a quick event which causes the sudden disappearance of the light when the lights were turned off in the room.

\section{The fragmenting metaphor}

Behind explanations categorized to express the fragmenting metaphor seemed to be some idea that the light was breaking to invisible small fibres or particles and making it invisible:

"The rays of the light are divided around the room in really small parts and we do not see them."

“...the light drowns in the darkness. It breaks into atoms."

\section{The carrying metaphor}

In the explanations in accordance with this metaphor, the light does not in fact disappear at all; the light is more like finding the road out of the room:

"Light will go out for example of the window."

“... light goes out of the room at the speed of light.. ".

"Light disappears into the emptiness."

"Light disappears into the snowdrift"

"Light is so quick that it goes out of small chinks."

"It will go out of the keyhole"

"Out is so wide an area that the light is divided outside and the light is so small that it is scarcely seen." 
Some respondents thought that it was possible also to carry the light out of the darkening room into another well-lit room, as if the light were seeking another light.

"Light will go to some other light place."

In some of the children's descriptions the darkness also moves in as concretely as the light goes out. In these pupils' opinion, the darkness is not merely the property of the room where is no light but to them also the darkness seems to appear as a real entity which can move in the same way as a light:

“... darkness will come from outside to inside."

“...darkness will come over the light.”

“...Darkness will come and the light does not give way, so the light stays under."

\section{Metaphor of the struggle between light and darkness}

In this metaphor, the light and the darkness are to each other like material enemies who fight for the space to live and one or the other must give way or die:

"The darkness will eat the light."

"Light beats the darkness."

"Light dies."

"The darkness will win or fill the state when the light goes away."

"The darkness conquers the room and destroys light."

In children's thinking light and darkness can also assume the characteristics of mixing fluids or gases:

"Light mixes with darkness, it gets dusky."

\section{The absorption metaphor}

In the explanations classified under this metaphor it was thought that the light was somehow absorbed into the walls, objects, clothes etc.:

"Light disappears into the objects."

In some cases, the explanation contained both the idea of absorption and the idea of a struggle between light and darkness:

"The light which has come last disappears into the walls as if there were some war going on but the darken side would win. The light goes so far as it gets and then will die out"

One might suppose that the metaphor of the absorbing of the light expresses the incipient idea of absorption of the light. However no pupil from whom I had an authentic explanation for an original question clearly expressed an idea of the fact that a part of the light will be reflected and the other part will be absorbed as the light meets the surface. 
The bulk of the children's explanations for the disappearing of the light could be quite naturally classified under the six metaphors presented above. Of course, quite imaginative explanations for the problem were also obtained such as the following;

[Light] "becomes a black light."

[Light] "draws away into the second dimension."

\section{RELATIVE FREQUENCY OF THE METAPHORICAL EXPLANATIONS}

The main objective of this study was to classify the explanations given by the pupils for the disappearance of light by qualitative methods and not to ascertain the frequencies of the different types of explanations evinced by pupils for the problem stated. However, from the teachers' reports we also get a preliminary picture of the relative frequencies of the metaphorical classifications. Most commonly the fifth and sixth graders seemed to trust explanations which could be classified under the circulation metaphor. Many teachers estimated that approximately every third pupil trusted this explanation model and in some classes as many as half of the explanations fitted into this category. The next common metaphors on which pupils relied were the evaporation metaphor, the fragmenting metaphor and the carrying metaphor. One of the teachers wondered in her report about the fact that only a few of her pupils proposed that the light was being carried out from the windows although she had supposed that it would be the most common explanation offered by her pupils for the disappearing of the light.

\section{Discussion}

As stated above the data acquisition of the study was carried out so that each teacher who participated in our in-service course asked his/her pupils or his/her colleague's pupils to explain the phenomena described in the inquiry tasks. After collecting the material teachers were asked to categorise the explanations which the pupils have given based on their own understanding. The method has its advantages and shortcomings. The fact that the teachers were familiar with their pupils' ways of thinking and expressing themselves increased the reliability of the first level interpretation of the data. The method of the study also made it possible to collect a lot of information about the children's interpretations because the pupils of nearly two hundred teachers answered the questions. On the other hand only a part of the data I had consisted of authentic explanations given by the children $(n=93)$ themselves. The fact that the second level interpretation, the qualitative analysis of the data was directed at the already classified data can be considered a limitation of the method. Our analysis ended up with the interpretation in which the pupils' answers were grouped into six metaphors. However, we consider that the metaphorical analysis we applied is a promising method to study children's preconceptions both for researchers and for teachers working at school.

In the continuation of this study, we have also planned to analyze the relative frequency of the above-mentioned metaphorical categories quantitatively. Before this is possible, we must achieve a better description of the categories into which pupils' explanations should be classified to the teachers.

According to our knowledge there are no previous studies available where we could compare our findings about children's preconceptions of the disappearance of light. The explanations which I got to the problem show quite clearly that children try to handle the phenomenon through the metaphors by which they are used to explain the phenomena of the macro-world. In this respect, the results are in accordance with the findings which Reiner et al. (2000) has reported about children's common conceptions considering other features of light. The most typical metaphor by which pupils explained the disappearance of light was the circulation metaphor. In this kind of 
explanation light went back to electric wires, inside the lamp, to the wall socket, to the fuse etc. When I discussed this with the teachers they assumed that children use the circulation metaphor so commonly because they have used similar explanations so often in other contexts like for example in the context where water circulates in the nature and in the pipes of the central heating system or electrons circulate in the closed electric circuit and so on. Most pupils at grades 5 to 6 seemed to know that the light is somehow produced by the electricity corresponding for example the findings of Brophy and Allemani (2003). Reiner (1987) found in his study that many 12 to13 year old pupils seemed to conceptualize light as a stream of liquid or particles. The explanations which I have here classified under the headings of the evaporation metaphor and the fragmenting metaphor seem to express the same kind of thinking. In some cases which I categorized under the metaphor of the struggle between light and darkness also the darkness seemed to get properties of fluid: light was explained to mix with darkness or to flow to an other place etc. When a pupil tries to handle the phenomenon of the disappearance of light he or she inevitably faces the same basic questions which have proved to be central in understanding light phenomena in general. The questions are: whether light is a static entity or something that travels, how light interacts with objects and how light and lightness relate to each other. Different opinions which pupils seemed to have on these questions followed the line which is well known from the earlier studies concerning other light phenomena than the disappearance of light (cf. Reiner et al. 2000, van Zee et al., 2005).

The disappearance of light does not belong to the core content of the science curriculum at primary school level in Finland and it is not expected that children would on this level be able to explain the phenomenon in an accurate way. Despite this, the study that was made in the cooperation with the teachers gave a lot of indirect information about the children's way to understand the essence of the light. The knowledge of these common preconceptions enables teachers to take account of these preconceptions more effectively in their teaching. Furthermore, the study offered them an opportunity to get acquainted with how they can study their pupils' preconceptions as a part of their daily practice.

However, the careful choice of the inquiry tasks is a central factor when teachers are encouraged to study their pupils' preconceptions. The tasks should be inspiring and challenging at the same time for the teachers of the lower level of the comprehensive school and to their pupils. Furthermore, the tasks should be of such nature that even from the view point of the experienced teacher the explanations given by the pupils are to some extent so surprising that the teacher would regard the study of preconceptions as a sensible way to develop self as a science teacher.

\section{REFERERENCES}

Ahtee, M. (1992). Oppilaiden käsitykset valo-opin ilmiöistä ja niiden ottaminen huomioon opetuksessa [Pupils' conceptions of the optical phenomena and taking account these in the teaching]. Helsingin yliopiston opettajankoulutuslaitos. Tutkimuksia 102. Helsinki: Yliopistopaino.

Andersson, B., \& Kärrqvist, C. (1983). How Swedish pupils, aged 12-15 years, understand light and its properties. European Journal of Science Education, 5(4), 387-402.

Brophy, J., \& Alleman, J. (2003). Primary-grade students' knowledge and thinking about the supply of utilities (water, heat, and light) to modern homes. Cognition and Instruction, 21(1), 79-112.

Dedes, C. (2005). The mechanism of vision: Conceptual similarities between historical models and childrens's representation. Science \& Education, 14, 699-712.

Driver, R., Squires, A., Rushworth, P., \& Wood-Robinson, V. (2000). Dando sentido a la ciencia en secundaria. Investigaciones sobre las ideas de los niños. Biblioteca para la actualización del maestro. 
Duit, R. (2006). Bibliography. Students' alternative frameworks and science education STCSE. Institut für die Pädagogik der Naturwissenschaften an der Universität Kiel, (http://www.ipn. uni-kiel.de/aktuell/stcse/stcse.html).

Galili, I., \& Lawrik, V. (1998). Flux concept in learning about light: A critique of the present situation. Science Education, 82(5), 591-613.

Guesne, E. (1985). Light. In R. Driver, E. Guesne, \& A. Tiberghien (Eds.), Children's ideas in science (pp.10-32). Philadelphia, PA: Open University Press.

Happonen, S. (2000). Kertomisen ja metaforan hurma - kasvatustieteellisen tutkimuksen uudet puhunnat [The fascination of storytelling and metaphor - the new paroles in the research of educational sciences]. In I. Buchberger (Ed.), Opettaja ja aine. Ainedidaktiikan symbosiumi 4.2.2000. Osa 2. Helsingin yliopiston opettajankoulutuslaitos. Tutkimuksia 225. (pp.801-812). Helsinki: Hakapaino.

Havu, S. (2000). Changes in children's conceptions through social interaction in pre-school science education. Joensuun yliopiston kasvatustieteellisiä julkaisuja, n:o 60.

Hierrezuelo M. J., \& Montero M. A. (1988). La ciencia de los alumnos. Su utilización en la didáctica de la Física y la Quimica. Ed. Laia/Ministerio de Educación y Ciencia.

Jung, W. (1981, September 14-16). Conceptual frameworks in elementary optics. In the Proc. of the International Workshop on Problems Concerning Students' Representations of Physics and Chemistry Knowledge, Ludvigsburg, Germany.

Kövecses, Z. (2005). Methaphor in Culture. Universality and Variation. Cambridge: Cambridge University Press.

Lakoff, G. and Johnson, M. (1999). Philosophy in the flesh: The embodied mind and its challenge to Western thought. New York: Basic Books.

Langley, D., Ronen, M. \& Eylon, B.-S. 1997. Light propagation and visual patterns: Preinstruction learners' conceptions. Journal of Research in Science Teaching, 34(4), 399-424.

Levävaara, H. (1997). Opettajan ja oppilaan käsitysten kohtaaminen. Avoin tutkimus peruskoulun valo-opin opetuksessa [The compatibility of the teacher's and pupil's conceptions. The open inquiry in teaching optics at the comprehensive school]. Helsingin yliopiston opettajankoulutuslaitos. Tutkimuksia 174. Helsinki:Yliopistopaino.

Mahlios, M., \& Maxson, M. (1998). Metaphors as structures for elementary and secondary preservice teachers' thinking. International Journal of Educational Research, 29(3), 227-240.

Martinez, M.A., Sauleda, N., \& Huber, G.L. (2001). Metaphors as blueprints of thinking about teaching and learning. Teaching and Teacher Education, 17(8), 965-977.

Mayer, R.E. (2004). Teaching of subject matter. Annual Review of Psychology, 55, 715-744.

Olivieri, G., Torosantucci, G., \& Vicentini, M. (1988). Colored shadows. International Journal of Science of Education, 10(5), 561-569 10.

Pavlos, M., \& Panagiotis, A. (2005). Historical approach to the teaching of the linear propagation of light, ahadows and pinhole cameras. Science \& Education, (6-7), 675-697.

Presmeg, N.C. (1992). Prototypes, metaphors, metonymies and imaginative rationality in high school mathematics. Educational Studies in Mathematics, 23(6), 595-610.

Presmeg, N.C. (1998). Metaphoric and metonymic signification in mathematics. Journal of Mathematical Behavior, 17(1), 25-32.

Presmeg, N. (2004). Use of personal metaphors in the learning of mathematics. Paper presented in the Topic Study Group 25 of the 10th International Congress of Mathematics Education ICME 10, Copenhagen (Denmark) http://www.icme-organisers.dk/tsg25/plenary/presmeg. doc.

Reiner, M. (1987). Real time computer based analysis in physics laboratory, as a means for changing students' conceptual frameworks in physics. Unpublished master's thesis, Technion, Israel Institute of Technology.

Reiner, M., Slotta, J.D., Chi, M.T.H., \& Resnick, L.B. (2000). Naive Physics Reasoning: A Commitment to Substance-Based Conceptions. Cognition \& Instruction, 18(1), 1-34. 
Rintakumpu, E (2001). Valon mallit oppikirjoissa ja opiskelijoiden tulkitsemina [The models of light in textbooks and interpreted by students]. Joensuun yliopisto. Fysiikan koulutusohjelma. Opettajan suuntautumisvaihtoehto. http://physics.joensuu.fi/publications/gradu/gradu_er.pdf.

Saari, H. (2000). Oppilaiden käsitykset malleista ja mallintaminen fysiikan perusopetuksessa. [Students' conceptions of models and modeling in basic teaching of physics]. University of Joensuu. Department of Physics. Väisälä Laboratory. Dissertations; 22.

Saari, H. \& Viiri, J. 1998. Kokeellisuus ja mallintaminen luonnontieteissä [Experimentality and modeling in science]. Helsinki: Opetushallitus.

Slotta, J.D., Chi, M.T.H., \& Joram, E. (1995). Assessing students' misclassifications of physics concepts: An ontological basis for conceptual change. Cognition \& Instruction, 13(3), 373-400.

Tolska, T., (2002). Kertova mieli. Jerome Brunerin narratiivikäsitys [The telling mind. Jerome Bruner's conception of the narrative]. Helsingin yliopisto. Kasvatustieteen laitos. Tutkimuksia 178. Helsinki: Yliopistopaino.

van Zee, E.H., Hammer, D., Bell M. \& Roy, P. (2005). Learning and teaching science as inquiry: A case study of elementary school teachers' investigations of light. Science Education, 89(6), 1007-1042. 